\title{
Drivers of trophic amplification of ocean productivity trends in a changing climate
}

\author{
C. A. Stock, J. P. Dunne, and J. G. John \\ NOAA Geophysical Fluid Dynamics Laboratory, 201 Forrestal Road, Princeton, NJ 08540-6649, USA \\ Correspondence to: C. A. Stock (charles.stock@noaa.gov)
}

Received: 12 June 2014 - Published in Biogeosciences Discuss.: 24 July 2014

Revised: 22 October 2014 - Accepted: 12 November 2014 - Published: 16 December 2014

\begin{abstract}
Pronounced projected 21st century trends in regional oceanic net primary production (NPP) raise the prospect of significant redistributions of marine resources. Recent results further suggest that NPP changes may be amplified at higher trophic levels. Here, we elucidate the role of planktonic food web dynamics in driving projected changes in mesozooplankton production (MESOZP) found to be, on average, twice as large as projected changes in NPP by the latter half of the 21 st century under a high emissions scenario in the Geophysical Fluid Dynamics Laboratory's ESM2M-COBALT (Carbon, Ocean Biogeochemistry and Lower Trophics) earth system model. Globally, MESOZP was projected to decline by $7.9 \%$ but regional MESOZP changes sometimes exceeded 50\%. Changes in three planktonic food web properties - zooplankton growth efficiency (ZGE), the trophic level of mesozooplankton (MESOTL), and the fraction of NPP consumed by zooplankton (zooplankton-phytoplankton coupling, ZPC), explain the projected amplification. Zooplankton growth efficiencies (ZGE) changed with NPP, amplifying both NPP increases and decreases. Negative amplification (i.e., exacerbation) of projected subtropical NPP declines via this mechanism was particularly strong since consumers in the subtropics have limited surplus energy above basal metabolic costs. Increased mesozooplankton trophic level (MESOTL) resulted from projected declines in large phytoplankton production. This further amplified negative subtropical NPP declines but was secondary to ZGE and, at higher latitudes, was often offset by increased ZPC. Marked ZPC increases were projected for high-latitude regions experiencing shoaling of deep winter mixing or decreased winter sea ice both tending to increase winter zooplankton biomass and enhance grazer control of spring blooms. Increased ZPC ampli-
\end{abstract}

fied projected NPP increases in the Arctic and damped projected NPP declines in the northwestern Atlantic and Southern Ocean. Improved understanding of the physical and biological interactions governing ZGE, MESOTL and ZPC is needed to further refine estimates of climate-driven productivity changes across trophic levels.

\section{Introduction}

Under intensive greenhouse gas emissions scenarios (RCP8.5; Riahi et al., 2011), climate change is projected to result in a small to moderate decrease in global net primary production (NPP) by the end of the 21 st century (mean $=-8.6 \%$, range $=0-16 \%$; Bopp et al., 2013). This results mainly from enhanced nutrient limitation under strengthening surface ocean stratification (Bopp et al., 2001; Doney, 2006). Projected regional NPP changes, however, can be substantially larger than global mean trends and of opposite sign (Steinacher et al., 2010; Rykaczewski and Dunne, 2010). For example, in high-latitude systems particularly those subject to very deep winter mixing or prolonged periods of sea-ice coverage - nutrients are often in surplus and enhanced stratification may increase NPP by alleviating light limitation (Doney, 2006; Bopp et al., 2001). Large regional NPP changes raise the possibility of redistributions of marine resources and significant socioeconomic consequences (Merino et al., 2012; Sumaila et al., 2011; Barange et al., 2014). Furthermore, recent results suggest that trophic amplification - or the magnification of relative biomass/productivity changes across trophic levels via food web dynamics - could lead to significantly larger changes in 
fishery resources than implied by NPP changes alone (Chust et al., 2014).

Ryther (1969) hypothesized that differences in planktonic food web dynamics create much starker contrasts in fish yields across ecosystems than would be implied by more modest NPP gradients. Specifically, he posited that a relatively large number of low-efficiency trophic steps in lowproductivity oceanic systems greatly attenuate the importance of these systems for fishery yields. In contrast, a relatively small number of high-efficiency trophic steps in upwelling systems could greatly amplify contributions to fishery yields relative to what NPP alone would suggest. The corollary of this hypothesis, that NPP alone is a poor indicator of fishery yields across global marine ecosystems, is supported by recent analysis (Friedland et al., 2012). Furthermore, inspection of the role of the food web mechanisms invoked by Ryther in sharpening higher trophic level productivity gradients between ocean ecosystems using modern data constraints supports their importance. The size of cross-ecosystem differences, however, were muted relative to the very stark differences invoked by Ryther, and cross-ecosystem contrasts in the degree of zooplanktonphytoplankton coupling was raised as an additional consideration (Stock et al., 2014).

Mechanisms leading to the amplification of spatial NPP differences may also amplify projected NPP trends in a changing climate. The present study examines the role of each of the planktonic food web factors described above consumer growth efficiency, the length of food chains, and zooplankton-phytoplankton coupling - in amplifying projected 21st century mesozooplankton production (MESOZP) trends relative to NPP. The planktonic ecosystem model used is distinguished by extensive evaluation against observationbased energy flux estimates throughout the planktonic food web (Stock et al., 2014). We show that nearly all of the projected twofold amplification of NPP changes for MESOZP is explained by changes in these food web factors and explicitly quantify the roles of each mechanism. Lastly, results are used to identify aspects of planktonic food web dynamics in need of further study and/or improved representation within models to build further confidence in trophic amplification estimates under climate change.

\section{Methods}

\subsection{ESM2M-COBALT}

To conduct this analysis, the Carbon Ocean Biogeochemistry and Lower Trophics (COBALT) planktonic ecosystem model (Stock et al., 2014) was integrated with GFDL's (Geophysical Fluid Dynamics Laboratory) earth system model ESM2M (Dunne et al., 2012, 2013). ESM2M is a member of the latest generation of coupled carbon-climate earth system models used for the Coupled Model Intercomparison Project Phase

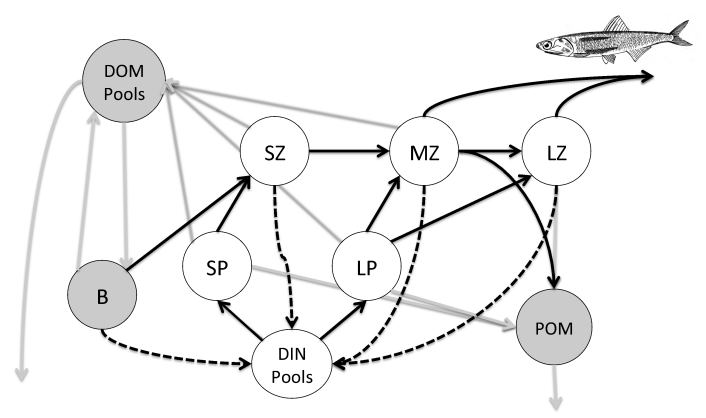

Figure 1. Simplified schematic of planktonic food web dynamics within COBALT. DIN Pools - diverse pools of dissolved organic nutrients (e.g., $\mathrm{NH}_{4}, \mathrm{NO}_{3}, \mathrm{Fe}, \mathrm{PO}_{4}, \mathrm{SiO}_{4}$ ); $\mathrm{SP}$ - small phytoplankton; LP - large phytoplankton; $\mathrm{SZ}$ - small zooplankton (i.e., microzooplankton); MZ - medium zooplankton (i.e., small to mediumbodied copepods); LZ - large zooplankton (i.e., large copepods and euphausiids/krill); DOM Pools - dissolved organic matter pools of various lability; B - free-living heterotrophic bacteria; POM - particulate organic material. Fish enter the model as a closure term on $\mathrm{MZ}$ and LZ. Arrows indicate exchange of material between groups. Dashed arrows are reserved for respiration/remineralization of organic matter. Downward arrows for POM indicate sinking. A downward arrow is also shown for DOM to indicate that the downward mixing of long-lived DOM can also create significant export of organic material from the euphotic zone in the model.

5 (CMIP5; Flato et al., 2013), which has informed the 5th Assessment Report of the Intergovernmental Panel on Climate Change (IPCC-AR5). Its physical origin is GFDL's CM2.1 climate model (Delworth et al., 2006). ESM2M has moderate transient and equilibrium climate sensitivities of 1.5 and $3.2^{\circ} \mathrm{C}$ (Winton et al., 2013) compared to the assessed likely range among climate models of $1-3$ and $2-4.5^{\circ} \mathrm{C}$, respectively (Meehl et al., 2007). It captures regional surface climate patterns (Reichler and Kim, 2008), modes of interannual variability (Guilyardi et al., 2009) and historical climate change (Hegerl et al., 2007; Flato et al., 2013).

ESM2M-COBALT simulations were initiated from a 2400-year preindustrial ESM2M spin-up. An additional 1000 years of preindustrial control was run with ESM2MCOBALT, followed by 160 years of land-use spin-up, a historical simulation from 1860 to 2005 , and a projection to 2100 under the high emissions RCP8.5 scenario (Riahi et al., 2011). The ocean component of ESM2M is GFDL's MOM4p1 (Modular Ocean Model; Griffies, 2009). It has a $1^{\circ}$ horizontal grid that ramps to finer $1 / 3^{\circ}$ resolution at the Equator and is tripolar above $65^{\circ} \mathrm{N}$ (Griffies et al., 2005). It includes 50 geopotential vertical levels spaced approximately $10 \mathrm{~m}$ apart in the top $200 \mathrm{~m}$ with coarser resolution below. The atmospheric component of ESM2M is provided by GFDL's AM2 model (Anderson et al., 2004; Lin, 2004) and has a horizontal resolution of $2^{\circ} \times 2.5^{\circ}$.

COBALT uses 33 state variables to resolve global-scale cycles of nitrogen, carbon, phosphate, silicate, iron, calcium 

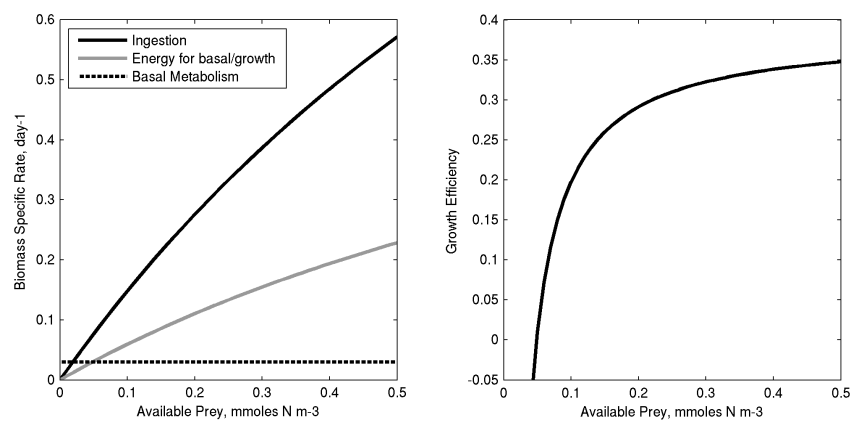

Figure 2. Summary of zooplankton feeding and growth efficiency as a function of food availability. The example shown is for medium zooplankton at $20^{\circ} \mathrm{C}$. In the left panel, the dashed line indicates the basal metabolic rate that remains constant for all levels of prey resources. The solid black line shows the grazing rate as a function of available prey resources and the solid grey line indicates the energy remaining after removing undigested food (30\% of ingestion) and accounting for active metabolism (30\% of ingestion). The energy available for growth is thus the difference between the grey line and the dashed line. The panel on the right shows the resulting growth efficiency (zooplankton production/ingestion), which is negative when the energy remaining (grey line) is less than that needed to cover basal metabolic costs and rises to a maximum value as ingestion rates become large relative to basal metabolic costs.

carbonate, oxygen and lithogenic material. Figure 1 provides a distilled depiction of the planktonic food web dynamics. We note that the structure itself is similar to other intermediate complexity planktonic food web models used in global and regional physical-biological simulations (e.g., Aumont et al., 2003; Chai et al., 2002; Kishi et al., 2007) and ESM2M-COBALT exhibits similar overall fidelity to global nutrient and chlorophyll distributions as ESM2M (Dunne et al., 2013). COBALT is unique, however, in the extent to which it is has been critically assessed and calibrated against large-scale observed patterns in the flux of carbon and energy throughout the planktonic food web (Stock et al., 2014; Stock and Dunne, 2010). Most critically for the analysis herein, the model produces NPP and MESOZP estimates that are broadly consistent with observation and satellitebased estimates (Stock et al., 2014). Here we provide a brief overview of the planktonic food web dynamics in COBALT (Fig. 1), highlighting dynamics governing the food web processes central to the objectives herein. Complete details can be found in Stock et al. (2014).

Inorganic nutrients are taken up by phytoplankton falling into small and large size classes (SP and LP), where the large group is a mix of diatoms (assumed dominant when silicate is plentiful) and other phytoplankton with a nominal lower size bound of $\sim 10 \mu \mathrm{m}$. Primary production is determined by light (Geider et al., 1997), the most limiting nutrient (nitrogen, phosphorous, iron) and metabolic costs (Geider, 1992; Flynn, 2005). Phytoplankton are consumed by small, medium, and large zooplankton groups (SZ, MZ, and LZ), where small zooplankton are microzooplankton $<200 \mu \mathrm{m}$ in equivalent spherical diameter (ESD), medium zooplankton are smallto medium-bodied copepods ( $200 \mu \mathrm{m}-2 \mathrm{~mm}$ ESD), and large zooplankton are large copepods and euphausiids $(2 \mathrm{~mm}-$ $2 \mathrm{~cm}$ ESD). Predator-prey size ratios were chosen based on typical ratios observed for ciliates and copepods (Fuchs and Franks, 2010; Hansen et al., 1994). Feeding is modeled as a type II saturating response with weak densitydependent switching between herbivory and carnivory (Stock et al., 2008). Higher predators (i.e., fish) enter the model as a density-dependent mortality on medium and large zooplankton, reflecting an assumption that the biomass of unresolved higher predators scales with the available biomass of their zooplankton prey.

Zooplankton consumers of phytoplankton must compete with losses due to viruses, exudation and aggregation for organic material fixed by phytoplankton. The balance of these competing rates plays a central role in determining the strength of zooplankton-phytoplankton coupling. Exudation is assumed to be $13 \%$ of primary production (Baines and Pace, 1991) and is routed to labile dissolved organic material. Viruses are assumed a minor phytoplankton loss mechanism (Suttle, 1994) and are included as a weak densitydependent loss term for small phytoplankton. This contrasts with the stronger density-dependent viral loss term imposed on bacteria, which routes $10-40 \%$ of bacterial production back to dissolved organic material (Suttle, 1994; Fuhrman, 2000). Aggregation is modeled as a density-dependent loss term for small and large phytoplankton (Doney et al., 1996) calibrated for consistency with the size-specific thresholds for aggregation-based control of phytoplankton accumulation derived by Jackson (1990).

Not all the material consumed by zooplankton is realized as zooplankton production. In total, $30 \%$ of ingested material is egested, yielding an assimilation efficiency (ae) of $70 \%$ (Carlotti et al., 2000; Nagata, 2000). An additional 30\% of ingestion is allocated to active metabolism (i.e., metabolic costs associated with feeding), leaving $40 \%$ to cover basal metabolic costs and support production (i.e., growth and reproduction). Biomass-specific basal metabolic rates are assumed to scale with maximum ingestion rates (Flynn, 2005) and must be covered before any net zooplankton production is realized (Fig. 2a). The zooplankton growth efficiency (ZGE, the ratio of net zooplankton production to ingestion) is thus negative at very low ingestion rates (i.e., there is a net loss of carbon to respiration) before increasing toward an asymptotic maximum just below $40 \%$ (Fig. 2b), consistent with observations of Straile (1997) and Hansen et al. (1997). The limitations of this relatively simple approach to zooplankton energetics will be addressed in detail in Sect. 4.

Size-based (i.e., allometric) relationships were used to parameterize phytoplankton groups, zooplankton groups and their interactions (Stock et al., 2014). The primary trade-off for phytoplankton is that small phytoplankton can efficiently scavenge nutrients in oligotrophic systems due to their high 

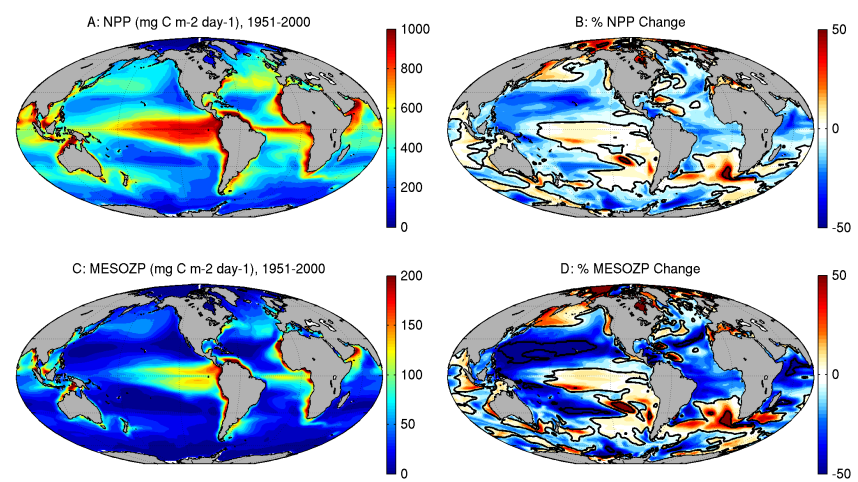

Figure 3. Contemporary (1951-2000) NPP and MESOZP (a, c) and percent changes between 2051-2100 and 1951-2000 (b, d). For regions with NPP > $25 \mathrm{mg} \mathrm{C} \mathrm{m}^{-2} \mathrm{day}^{-1}$ in 1951-2000 (see methods), the correlation between MESOZP change and NPP change is 0.86 and the magnitude of MESOZP changes is 2.1 times the NPP change. Contours are shown at $-50,0$ and $+50 \%$.

surface area to volume ratio (Munk and Riley, 1952; Eppley et al., 1969; Edwards et al., 2012), but are susceptible to voracious small zooplankton grazing (Hansen et al., 1997). Biological rates in the model are given a $Q_{10}$ of 1.88 (Eppley, 1972). That is, rates increase by a factor of 1.88 for a $10^{\circ} \mathrm{C}$ change in temperature. There are two exceptions: (1) phytoplankton aggregation was assumed to be a predominantly physical process; and (2) detrital remineralization was assumed to be modulated by mineral ballasting (Klaas and Archer, 2002; Armstrong et al., 2002). Both of these processes were thus given a $Q_{10}$ of 1 .

Calibration of the model food web dynamics involved tuning two parameters which are both highly uncertain and have a large effect on emergent food web dynamics (Stock and Dunne, 2010). Zooplankton basal metabolic rates were tuned within uncertainty ranges to ensure consistency with observed mesozooplankton biomass and productivity in subtropical gyres (Landry et al., 2001; Roman et al., 2002). Simultaneously, half-saturation constants for zooplankton feeding were calibrated to capture observed trends in the relationship between phytoplankton biomass and turnover times (Stock and Dunne, 2010). In both cases, tuning was done while maintaining the slope of allometric relationships across size classes (i.e., we allowed for 2 degrees of freedom rather than 6).

\subsection{Model diagnostics}

To assess trophic amplification within the planktonic food web, we compare the magnitudes of projected relative (i.e., percent) changes in MESOZP against projected relative changes in primary production (NPP). Larger percent MESOZP increases (decreases) in areas of increasing (decreasing) NPP indicate positive (negative) amplification.
MESOZP is the combined production of the medium and large zooplankton groups in Fig. 1. This is consistent with the definitions of Sieburth (1978) and reflects the resolution of the mesozooplankton observations that COBALT has been evaluated against (O'Brien, 2005). Production is integrated over $100 \mathrm{~m}$ and changes in production between 50 year means (1951-2000 and 2051-2100) are considered to help filter out climate variability in favor of the century-scale climate change signal of primary interest herein (Stock et al., 2011).

Where statistics of relative changes are calculated over model grid points, we limit calculations to regions where annual average productivity during the 1951-2000 period was greater than $25 \mathrm{mg} \mathrm{C} \mathrm{m}^{-2} \mathrm{day}^{-1}$. This threshold, which is 10-20 times less than production in oligotrophic subtropical gyres, omits $<0.05 \%$ of ocean area and just $0.001 \%$ of global NPP. This is done to ensure that statistics are not skewed by a small number of grid points where extremely low contemporary productivity yields extremely large relative changes (e.g., a change from 1 to $10 \mathrm{mg} \mathrm{C} \mathrm{m}^{-3}$ day $^{-1}$ ).

The ZGE metric is calculated as the mean of the zooplankton growth efficiencies from the three zooplankton groups. It thus provides a bulk measure of consumer growth efficiency for the system.

The mesozooplankton trophic level (MESOTL) metric is the ingestion-weighted average trophic level of medium and large zooplankton. For medium zooplankton, a trophic level of 1 was assigned to ingestion of large phytoplankton and a trophic level of 2 was assigned to ingestion of small zooplankton. For large zooplankton, ingestion of large phytoplankton was assigned a trophic level of 1 and ingestion of medium zooplankton was assigned a value of 1 plus the trophic level of medium zooplankton.

The zooplankton-phytoplankton coupling (ZPC) efficiency is the total ingestion of phytoplankton by all zooplankton groups divided by total phytoplankton production. It reflects the extent of consumer-prey coupling in the pelagic system.

\section{Results}

Globally, NPP in ESM2M-COBALT is projected to decline slightly, by $3.6 \%$, between $1951-2000$ and 2051-2100, from 54.7 to $52.7 \mathrm{PgC}_{\text {year }}{ }^{-1}$ (Fig. 3a, b). This is consistent in sign and of moderate magnitude compared with other model projections (Bopp et al., 2013; Steinacher et al., 2010). The sign of projected NPP changes also agrees with other models in regions where model consensus exists: NPP declines prevail throughout most low- and mid-latitude regions (Fig. 3a, b) due to enhanced nutrient limitation. Increasing NPP is more common at higher latitudes though marked regional variability exists. 
Table 1. Changes in physical and planktonic food web properties associated with regions where ZPC increases/decreases by more than 0.05 . The limiting nutrient is defined as that imposing the greatest limitation in the annual mean averaged over small and large phytoplankton types.

\begin{tabular}{lrrrrrrr}
\hline & Max MLD & $\begin{array}{r}\text { Max limiting } \\
\text { nutrient }\end{array}$ & $\begin{array}{r}\text { Min (winter) } \\
\text { phyto. biomass }\end{array}$ & $\begin{array}{r}\text { Min (winter) } \\
\text { zoop. biomass }\end{array}$ & $\begin{array}{r}\text { Max phyto. } \\
\text { biomass }\end{array}$ & $\begin{array}{r}\text { NPP change } \\
\text { ingestion of phyto. }\end{array}$ & $\begin{array}{r}\text { Phyto. aggregation } \\
\text { losses }\end{array}$ \\
\hline $\begin{array}{l}\text { Increased ZPC } \\
\text { regions }(>0.05)\end{array}$ & $-275 \mathrm{~m}$ & $-36 \%$ & $+35 \%$ & $+67 \%$ & $-5 \%$ & $+11 \%$ \\
$\begin{array}{l}\text { Decreased ZPC } \\
\text { regions }(<-0.05)\end{array}$ & $+86 \mathrm{~m}$ & $+59 \%$ & $-12 \%$ & $-37 \%$ & $+17 \%$ & $+34 \%$ & $+12 \%$ \\
\hline
\end{tabular}
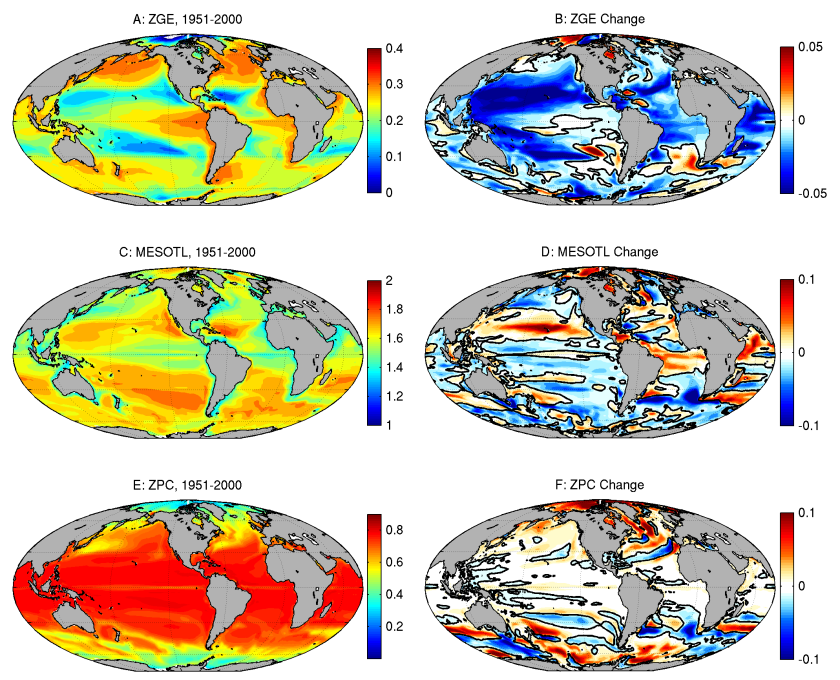

Figure 4. Contemporary (1951-2000) planktonic food web characteristics (ZGE, MESOTL, and ZPC) and changes in these properties: (2051-2100)-(1951-2000). The 0 contour is shown.

Regional NPP variations are often larger than global mean changes (Fig. 3b) and depend on detailed balances of evolving nutrient and light limitation. Full diagnosis of regional changes is beyond the objective of this contribution. It is notable, however, that a modest NPP increase is projected in the central and eastern equatorial Pacific despite its low latitude. This has also been found in some other models (Ruggio et al., 2013) where it has been associated with increased iron in the Equatorial Undercurrent. Large portions of the interior Southern Ocean, in contrast, exhibit declining NPP in ESM2M-COBALT despite its high latitude. Very strong iron limitation and minimal iron deposition in this region place great importance on the supply of iron from depth, favoring deeper mixing for higher NPP even though light is often scarce.

Projected changes in MESOZP are highly correlated ( $r=0.86)$ with NPP but broadly amplified in both positive and negative directions (Fig. 3c, d). The mean magnitude of percent changes in MESOZP is 2.1 times the percent of change in NPP and approximately equal in both the positive (2.2 times) and negative (2.0 times) directions. Globally,
MESOZP declines by $7.9 \%$ from 5.35 to $4.93 \mathrm{Pg} \mathrm{C}_{\mathrm{Cear}}{ }^{-1}$, but regional changes can be $\sim 50 \%$.

Trends in planktonic food web properties are summarized in Fig. 4. ZGE changes show a strong positive correlation with NPP changes ( $r=0.82$; Fig. $4 \mathrm{a}$, b). Like NPP, ZGE declines are ubiquitous in low and mid latitudes. The largest ZGE declines occur within oligotrophic subtropical gyres where decreases to already low NPP further reduces small energy surpluses available for growth over basal metabolic costs. Since feeding rates are well below saturating levels, further declines in food resources are fully reflected in decreased feeding rates (Fig. 2). Likewise, increasing productivity in previously low NPP regions, such as the western Arctic Ocean, lead to pronounced ZGE increases.

Projected changes in mesozooplankton trophic level (MESOTL) are generally modest $(<0.1$ acting on a range of annual mean MESOTL between 1.4 and 1.8; Fig. 4c, d). In lower latitudes (between $50^{\circ} \mathrm{S}$ and $50^{\circ} \mathrm{N}$ ), there is a strong negative correlation between projected MESOTL and NPP changes $(r=-0.70)$ that strengthens $(r=-0.78)$ if only large phytoplankton productivity is considered (not shown). This reflects less mesozooplankton herbivory and higher MESOTL with declining phytoplankton production. The correlation breaks down poleward of $50^{\circ}$ latitude, however, where dynamic ZPC shifts that also influence the extent of herbivory are projected (Fig. $4 \mathrm{e}, \mathrm{f}$ ).

ZPC generally increases with climate change (Fig. 4e, f). This reflects the favorability of increased surface ocean stratification for consumer-prey coupling in the pelagic zone. ZPC changes are largest at mid and high latitudes and the largest increases are closely aligned with regions experiencing pronounced shoaling in the depth of winter mixing (e.g., northwestern Atlantic and many parts of the Southern Ocean; Fig. 5). In the model, shoaling winter mixed layers yield decreased winter nutrient maxima and increased winter phytoplankton and zooplankton biomass (Table 1). The particularly pronounced increase in winter zooplankton biomass combines with decreased winter nutrients to enable zooplankton to respond more effectively to the spring bloom, shifting the balance of phytoplankton loss toward zooplankton consumption and away from aggregation and direct sinking (Table 1). 


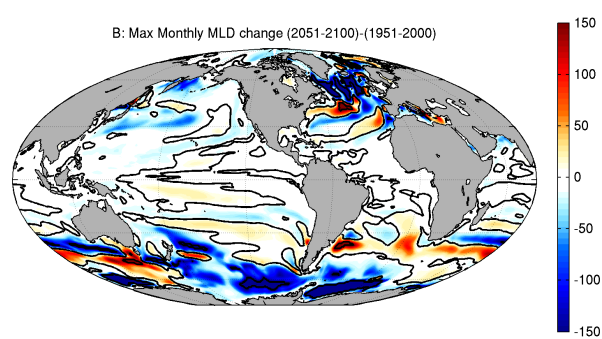

Figure 5. Change in the maximum monthly mixed layer depth (MLD, m): (2051-2100)-(1951-2000). The 0 contour is shown.

In contrast to ZGE and MESOTL, ZPC changes are not significantly correlated with NPP changes. This is because decreased mixing exhibits both positive and negative effects on high-latitude NPP depending on the prominence of nutrient versus light limitation while its effect on ZPC is uniformly positive.

To confirm and quantify the role of the food web factors in Fig. 4 in trophic amplification, we note that food web considerations suggest that MESOZP can be approximated as

$\mathrm{MESOZP} \cong \mathrm{ZPC} \cdot \mathrm{NPP} \cdot \mathrm{ZGE}^{\mathrm{MESOTL}}$,

where ZPC · NPP is the primary production consumed by all zooplankton and $\mathrm{ZGE}^{\mathrm{MESOTL}}$ accounts for the characteristic number and efficiency of trophic links of separating phytoplankton and mesozooplankton. Recalculating the percent MESOZP change with this approximation yields a very close match to the exact model solution (Fig. 6 compared with Fig. 3d, $r=0.98$ ). This confirms that changes in the planktonic food web factors used to explain contemporary spatial differences in the ratio of mesozooplankton production to primary production are also responsible for the trophic amplification of climate-change-driven productivity trends in Fig. 3.

The impact of individual planktonic food web factors on MESOZP changes was estimated using Eq. (1) while holding all but one factor constant across the two time periods (Fig. 7). Changes in ZGE are the most prominent contributor to trophic amplification (Fig. 7a). Both positive and negative NPP changes are amplified by ZGE changes, but the largest impact is negative amplification (i.e., exacerbation) of subtropical NPP declines due the dynamic variation of ZGE in low-food environments (i.e., Fig. 2). Increased MESOTL due to reductions in large phytoplankton productivity also amplifies subtropical declines, but its impact is secondary to ZGE (Fig. 7b).

Widespread ZPC increases under climate change have a positive influence on MESOZP changes (Fig. 7c; i.e., it exerts a stimulatory effect on mesozooplankton production). The effect, however, is only large in high-latitude regions experiencing large changes in winter mixing or ice coverage. Increasing ZPC plays a large role in the positive amplification of NPP increases in the Arctic but counteracts amplifica-

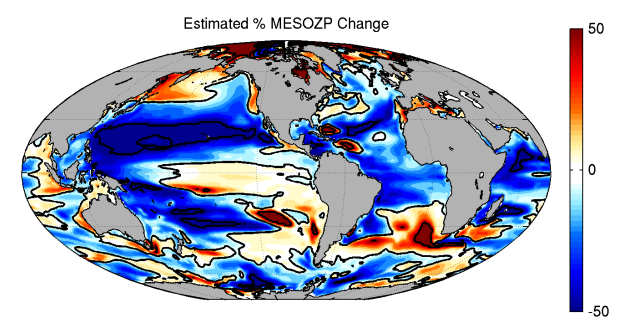

Figure 6. Estimated percent of MESOZP change based on the approximation in Eq. (1). The correlation with the exact solution (Fig. 3b) is 0.98. Contours are shown at $-50,0$ and $+50 \%$.

tion in most other regions. In regions where sharp decreases in winter mixing are associated with declining productivity (e.g., the northwestern Atlantic and many interior portions of the Southern Ocean; Figs. 3-5), increased ZPC counteracts negative amplification. from ZGE and MESOTL effects. In other regions of the Southern Ocean where strongly enhanced winter mixing is associated with increasing NPP, declining ZPC attenuates MESOZP increases. It is thus not surprising that regions with sharp ZPC shifts join transition areas between regions of positive and negative productivity changes to account for most of the $\sim 20 \%$ of ocean regions exhibiting trophic attenuation or opposing NPP and MESOZP changes (Fig. 8). The damping influence of ZPC in these regions, however, was not large enough to offset the dominant global pattern of trophic amplification.

\section{Discussion}

Results herein demonstrate the potential for significant trophic amplification of climate-change-driven NPP trends, with mean projected changes in ESM2M-COBALT MESOZP approximately twice as large as mean projected changes in NPP. While a difference between a $3.6 \%$ global NPP decline and $7.9 \%$ MESOZP decline may seem modest, results suggest that amplification may contribute to regional MESOZP changes as large as $50 \%$. Widespread trophic amplification is explicitly attributed to changes in three planktonic food web metrics: the ZGE, MESOTL, and the strength of ZPC - the same factors invoked to explain cross-biome differences in the transfer of energy between phytoplankton and fish (Ryther, 1969; Stock et al., 2014).

The potential for stark regional changes in ocean productivity has implications for food security. An important caveat, however, is that results herein reflect only one model. For NPP, alternative models agree on large-scale mean trends across latitudes, but these trends occur beneath substantial regional-scale variations where there is less consensus (Steinacher et al., 2010; Bopp et al., 2013). Likewise, Chust et al. (2014) found broad occurrence of trophic amplification under climate change across a suite of mainly regional physical-biological modeling frameworks, but the degree of 

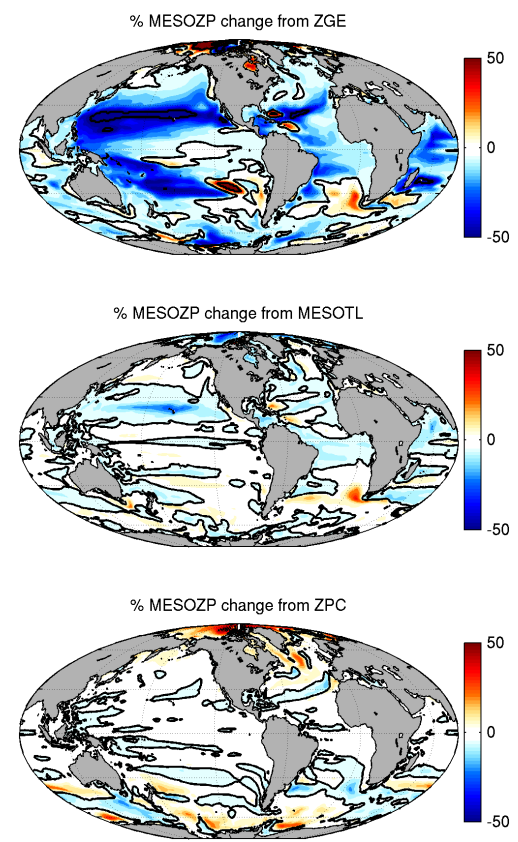

Figure 7. Contribution to percent of change in MESOZP due to evolving planktonic food web properties. Adding the changes above to the percent of change in NPP (Fig. 2b) yields the approximation of the percent of MESOZP change in Fig. 6 . The 0 contour is shown in all figures.

amplification was highly variable. Analysis of a global ensemble is clearly needed to further bound amplification estimates herein. There are several impediments, however, that must be resolved for such an analysis. First, many present generation ESMs have a highly simplified representation of planktonic food web dynamics that are incapable of resolving the interactions described herein (e.g., Dunne et al., 2005). Second, most biogeochemical models in present ESMs have not undergone detailed assessments against a holistic suite of available observation-based planktonic food constraints (Stock et al., 2014). Third, standard outputs lack the key diagnostics (e.g., ZGE, MESOTL, and ZPC) required to understand intermodel differences.

Focused field and laboratory research on the dynamics governing variation in ZGE, MESOTL and ZPC is also essential to refine projections. The ZGE effect was most notable for its marked negative amplification of declining NPP in many subtropical and temperate regions. The key aspect of the model structure that allows for this response is the inclusion of a basal metabolic cost that must be covered before any net production occurs. Without the inclusion of this modest rate $\left(<0.05\right.$ day $^{-1}$ for medium zooplankton at $20^{\circ} \mathrm{C}$; Fig. 2$)$, which is omitted in many models, no variation in ZGE and subsequent large-scale effects (Fig. 7a) would occur. As described in Sect. 2, the rate itself is difficult to measure and was thus calibrated to produce observed mesozooplankton production within the subtropics (Stock and Dunne, 2010).

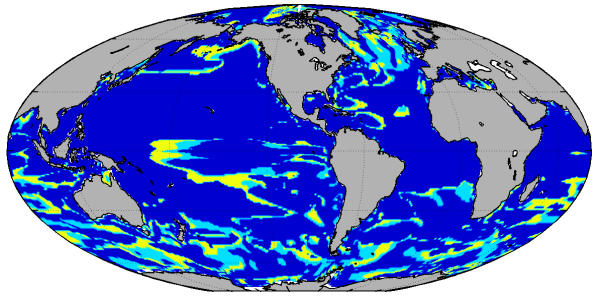

Figure 8. Areas of trophic amplification (dark blue) attenuation (light blue) and changes of opposite sign for NPP and MESOZP (yellow) in Fig. 3. Note that areas of trophic attenuation and changes of opposite sign often correspond to either (a) transition regions/fringes between areas increasing and decreasing NPP, or (b) areas with dynamic changes in ZPC that counteract the amplifying effects of ZGE and MESOTL (e.g., the subpolar North Atlantic and parts of the Southern Ocean).

Amplification via this ZGE mechanism occurs, however, as long as basal metabolic costs are not negligibly small relative to ingestion.

A possible ZGE variation not captured herein is a decrease at high ingestion rates due to a shortened residence time of food in the gut. This can be explained as a balance between clearance of food through the gut and energy extraction from that food to maximize production (Jumars et al., 1989). This effect, however, would likely not be a factor in oligotrophic subtropical systems where ZGE-driven amplification was most prominent. Furthermore, maximizing production places strong constraints on how much consumers can accommodate ZGE decreases before production declines.

The spatial ZGE patterns in Fig. 4a emerge as a result of calibrating the model to recreate cross-biome trends in the ratio of mesozooplankton production to primary production while also satisfying other observation-based constraints on the planktonic food web (Stock and Dunne, 2010). Improved observational constraints on cross-biome ZGE trends could build further confidence in projected responses. Syntheses of laboratory ZGE measurements has yielded some evidence for increasing ZGE across the range of food concentrations simulated herein $\left(\sim 10-100 \mathrm{mg} \mathrm{C} \mathrm{m}^{-3}\right)$ before dropping at very high concentrations (Straile, 1997; Hansen et al., 1997). The explanatory power of the food concentration, however, was weak $\left(r^{2}=0.29\right)$ and coverage of the lowest concentrations most essential to the response herein was limited to a few studies. For heterotrophic bacteria, in contrast, syntheses of large numbers of in situ measurements have yielded evidence for systematic trends similar in direction and magnitude to the ZGE patterns in Fig. 4a (del Giorgio and Cole, 2000). The importance of ZGE variations to trophic amplification under climate change provides further impetus for efforts to constrain cross-biome ZGE variations for zooplankton. 
The relatively small contribution of MESOTL changes to trophic amplification was surprising given that diatoms and/or large phytoplankton are projected to experience sharper declines under climate change than small phytoplankton (Bopp et al., 2001). In ESM2M-COBALT under RCP8.5, large phytoplankton production declines by $6.8 \%$ while small phytoplankton production declines by $2.3 \%$. Enhanced large phytoplankton declines arise from their higher sensitivity to declining nutrients relative to smaller cells, reflecting a disadvantage of the low surface area to volume ratio of large cells for nutrient scavenging. Two factors appear to minimize effects of this shift on MESOTL. First, the microbial food web (i.e., microzooplankton consuming small phytoplankton and bacteria) is prominent across all ocean biomes under contemporary ocean conditions (Calbet and Landry, 2004). A decrease in large phytoplankton production thus does not represent a binary switch from large to small phytoplankton dominance, but a more subtle shift in the relative importance of the large phytoplankton-copepod consumer link within an ocean where much of the energy flows (and is projected to continue to flow) through microzooplankton. Second, increasing ZPC compensates for decreasing large phytoplankton productivity in many of the areas experiencing the strongest increases in stratification by ensuring that a larger fraction of NPP is consumed by zooplankton (Fig. 7c).

Dynamic ZPC changes in high latitudes within ESM2MCOBALT had simple mechanistic explanations: very deep winter mixing is conducive to high winter nutrients and smaller prespring bloom zooplankton populations due to the combination of dilution via mixing and cumulative net losses over the unproductive winter season. This sets the stage for a large spring bloom controlled more strongly by aggregation than in less deeply mixed regions characterized by tighter coupling between phytoplankton and zooplankton consumers. A prominent aspect of mesozooplankton dynamics not resolved by ESM2M-COBALT that could influence this balance is diapause behavior in many copepod species, particularly in high-latitude oceans (Mauchline, 1998). Cues initiating and terminating dormancy, however, are complex and not fully understood (Dahms, 1995; Johnson et al., 2008). A complete examination of different diapause strategies for ZPC is beyond the scope of this work and requires novel approaches (Record et al., 2013) applied at global scales.

The other facet of ecosystem dynamics influencing ZPC in ESM2M-COBALT is aggregation. As described in Sect. 2, COBALT uses a simple density-dependent formulation (Doney et al., 1996) set to match theoretical size-dependent aggregation rates and critical concentrations derived by Jackson (1990). Any exploration of the impact of diapause on ZPC would thus also require consideration of more resolved formulations of particle aggregation dynamics. Particle coagulation theory provides a basis for further exploration, but significant uncertainties concerning controls on disag- gregation, particle stickiness, and the production of transparent exopolymer particles (TEP) remain (Burd and Jackson, 2009). Furthermore, incorporation of highly resolved particle size spectra used by many coagulation models into long-timescale, global simulations imposes a potentially prohibitive computational burden. Strategies are thus needed to efficiently capture emergent aggregation dynamics beyond the simple density dependence presently applied in many global models while maintaining low computational cost.

Finally, we note that trophic amplification and attenuation is unlikely to end with the planktonic food web. Kearney et al. (2013) examined amplification in a fisheries food web model based on principles from the widely applied Ecopath/Ecosim food web modeling framework (Pauly et al., 2000). The functional form of nonpredatory losses, which are intended to capture all losses not associated with consumption by other food web constituents (e.g., basal respiration, disease, cannibalism) proved an important determinant. Linear forms often used in Ecopath/Ecosim implementations were conducive to amplification in a manner analogous to the effect of basal respiration on ZGE herein (Fig. 2). In contrast, strong density-dependent losses (i.e., those associated with disease and cannibalism in limited carrying capacity environments) damped the effect of NPP variations. Integration of fish and planktonic food webs (e.g., Rose et al., 2010) would also allow for exploration of top-down perturbations that cannot be captured with simple higher predation closures used by planktonic food web models. Holistic accounting for amplification effects throughout the marine food web is needed to fully understand the implications of climate change for fishery yields.

Author contributions. C. A. Stock, J. G. John and J. P. Dunne designed and carried out simulations, formulated and refined the analysis and contributed to the writing of this manuscript.

Acknowledgements. The authors would like to thank Rebecca Asch and Désirée Tommasi for their constructive comments on early drafts that improved the paper.

Edited by: L. Bopp

\section{References}

Anderson, J. L., Balaji, V., Broccoli, A. J., Cooke, W. F., Delworth, T. L., Dixon, K. W., Donner, L. J., Dunne, K. A., Freidenreich, S. M., Garner, S. T., Gudgel, R. G., Gordon, C. T., Held, I. M., Hemler, R. S., Horowitz, L. W., Klein, S. A., Knutson, T. R., Kushner, P. J., Langenhost, A. R., Lau, N. C., Liang, Z., Malyshev, S. L., Milly, P. C. D., Nath, M. J., Ploshay, J. J., Ramaswamy, V., Schwarzkopf, M. D., Shevliakova, E., Sirutis, J. J., Soden, B. J., Stern, W. F., Thompson, L. A., Wilson, R. J., Wittenberg, A. T., Wyman, B. L., and Dev, G. G. A. M.: The new GFDL 
global atmosphere and land model AM2-LM2: Evaluation with prescribed SST simulations, J. Climate, 17, 4641-4673, 2004.

Armstrong, R. A., Lee, C., Hedges, J. I., Honjo, S., and Wakeham, S. G.: A new, mechanistic model for organic carbon fluxes in the ocean based on the quantitative association of POC with ballast minerals, Deep-Sea Res.-Pt. II, 49, 219-236, 2002.

Aumont, O., Maier-Reimer, E., Blain, S., and Monfray, P.: An ecosystem model of the global ocean including $\mathrm{Fe}$, Si, P co-limitation, Global Biogeochem. Cy., 17, 1060, doi:10.1029/2001GB001745, 2003.

Baines, S. B. and Pace, M. L.: The production of dissolved organic matter by phytoplankton and its importance to bacteria: Patterns across marine and freshwater systems, Limnol. Oceanogr., 36, 1078-1090, 1991.

Barange, M., Merino, G., Blanchard, J. L., Scholtens, J., Harle, J., Allison, E. H., Allen, J. I., Holt, J., and Jennings, S.: Impacts of climate change on marine ecosystem production in societies dependent on fisheries, Nature Climate Change, 4, 211-216, doi:10.1038/Nclimate2119, 2014.

Bopp, L., Monfray, P., Aumont, O., Dufresne, J. L., Le Treut, H., Madec, G., Terray, L., and Orr, J. C.: Potential impact of climate change on marine export production, Global Biogeochem. Cy., 15, 81-99, 2001.

Bopp, L., Resplandy, L., Orr, J. C., Doney, S. C., Dunne, J. P., Gehlen, M., Halloran, P., Heinze, C., Ilyina, T., Séférian, R., Tjiputra, J., and Vichi, M.: Multiple stressors of ocean ecosystems in the 21st century: projections with CMIP5 models, Biogeosciences, 10, 6225-6245, doi:10.5194/bg-10-6225-2013, 2013.

Burd, A. B. and Jackson, G. A.: Particle aggregation, Annual Review of Marine Science, 1, 65-90, doi:10.1146/annurev.marine.010908.163904, 2009.

Calbet, A. and Landry, M. R.: Phytoplankton growth, microzooplankton grazing, and carbon cycling in marine systems, Limnol. Oceanogr., 49, 51-57, 2004.

Carlotti, F., Giske, J., and Werner, F. E.: Modeling zooplankton dynamics, in: Zooplankton methodology manual, edited by: Harris, R. P., Wiebe, P. H., Lenz, J., Skjoldal, H. R., and Huntley, M. E., Elsevier, New York, 571-667, 2000.

Chai, F., Dugdale, R. C., Peng, T. H., Wilkerson, F. P., and Barber, R. T.: One-dimensional ecosystem model of the equatorial pacific upwelling system. Part I: Model development and silicon and nitrogen cycle, Deep-Sea Res.-Pt. II, 49, 2713-2745, 2002.

Chust, G., Allen, J. I., Bopp, L., Schrum, C., Holt, J., Tsiaras, K., Zavatarelli, M., Chifflet, M., Cannaby, H., Dadou, I., Daewel, U., Wakelin, S. L., Machu, E., Pushpadas, D., Butenschon, M., Artioli, Y., Petihakis, G., Smith, C., Garcon, V., Goubanova, K., Le Vu, B., Fach, B. A., Salihoglu, B., Clementi, E., and Irigoien, X.: Biomass changes and trophic amplification of plankton in a warmer ocean, Glob. Change Biol., 20, 2124-2139, doi:10.1111/gcb.12562, 2014.

Dahms, H. U.: Dormancy in the copepoda - an overview, Hydrobiologia, 306, 199-211, doi:10.1007/Bf00017691, 1995.

del Giorgio, P. A. and Cole, J. J.: Bacterial energetics and growth efficiency, in: Microbial ecology of the oceans, edited by: Kirchman, D. L., John Wiley and Sons, Inc., New York, 289-325, 2000.

Delworth, T. L., Broccoli, A. J., Rosati, A., Stouffer, R. J., Balaji, V., Beesley, J. A., Cooke, W. F., Dixon, K. W., Dunne, J., Dunne, K.
A., Durachta, J. W., Findell, K. L., Ginoux, P., Gnanadesikan, A., Gordon, C. T., Griffies, S. M., Gudgel, R., Harrison, M. J., Held, I. M., Hemler, R. S., Horowitz, L. W., Klein, S. A., Knutson, T. R., Kushner, P. J., Langenhorst, A. R., Lee, H., Lin, S., Lu, J., Malyshev, S. L., Milly, P. C. D., Ramaswamy, V., Russell, J., Schwarzkopf, M. D., Shevliakova, E., Sirutis, J. J., Spelman, M. J., Stern, W. F., Winton, M., Wittenberg, A. T., Wyman, B., Zeng, F., and Zhang, R.: GFDL's CM2 global coupled climate models, Part I: Formulation and simulation characteristics, J. Climate, 19, 643-674, 2006.

Doney, S. C.: Oceanography - plankton in a warmer world, Nature, 444, 695-696, 2006.

Doney, S. C., Glover, D. M., and Najjar, R. J.: A new coupled, one-dimensional biological-physical model for the upper ocean: Applications to the JGOFS bermuda atlantic time-series study (BATS) site, Deep-Sea Res.-Pt. II, 43, 591-624, 1996.

Dunne, J. P., Armstrong, R. A., Gnanadesikan, A., and Sarmiento, J. L.: Empirical and mechanistic models for the particle export ratio, Global Biogeochem. Cy., 19, Gb4026, doi:10.1029/2004gb002390, 2005.

Dunne, J. P., John, J. G., Adcroft, A. J., Griffies, S. M., Hallberg, R. W., Shevliakova, E., Stouffer, R. J., Cooke, W., Dunne, K. A., Harrison, M. J., Krasting, J. P., Malyshev, S. L., Milly, P. C. D., Phillipps, P. J., Sentman, L. T., Samuels, B. L., Spelman, M. J., Winton, M., Wittenberg, A. T., and Zadeh, N.: GFDL's ESM2 global coupled climate-carbon earth system models, Part I: Physical formulation and baseline simulation characteristics, J. Climate, 25, 6646-6665, doi:10.1175/Jcli-D-11-00560.1, 2012.

Dunne, J. P., John, J. G., Shevliakova, E., Stouffer, R. J., Krasting, J. P., Malyshev, S. L., Milly, P. C. D., Sentman, L. T., Adcroft, A. J., Cooke, W., Dunne, K. A., Griffies, S. M., Hallberg, R. W., Harrison, M. J., Levy, H., Wittenberg, A. T., Phillips, P. J., and Zadeh, N.: GFDL's ESM2 global coupled climate-carbon earth system models, Part II: Carbon system formulation and baseline simulation characteristics, J. Climate, 26, 2247-2267, doi:10.1175/JcliD-12-00150.1, 2013.

Edwards, K. F., Thomas, M. K., Klausmeier, C. A., and Litchman, E.: Allometric scaling and taxonomic variation in nutrient utilization traits and maximum growth rate of phytoplankton, Limnol Oceanogr., 57, 554-566, doi:10.4319/lo.2012.57.2.0554, 2012.

Eppley, R. W.: Temperature and phytoplankton growth in the sea, Fisheries Bulletin, 70, 1063-1085, 1972.

Eppley, R. W., Rogers, J. N., and McCarthy, J. J.: Half-saturation constants for uptake of nitrate and ammonium by marine phytoplankton, Limnol. Oceanogr., 14, 912-920, 1969.

Flato, G., Marotzke, J., Abiodun, B., Braconnot, P., Chou, S. C., Collins, W., Cox, P., Driouech, F., Emori, S., Eyring, V., Forest, C., Gleckler, P., Guilyardi, E., Jakob, C., Kattsov, V., Reason, C., and Rummukainen, M.: Evaluation of climate models, in: Climate change 2013: The physical science basis, Contributions of working group I to the fifth assessment report of the intergovernmental panel on climate change, edited by: Stocker, T. F., Qin, D., Plattner, G.-K., Tignor, M., Allen, S. K., Boschung, J., Nauels, A., Xia, Y., Bex, V., and Midgley, P. M., Cambridge University Press, Cambridge, UK, 741-866, 2013.

Flynn, K. J.: Incorporating plankton respiration in models of aquatic ecosystem function, in: Respiration in aquatic ecosystems, edited by: del Giorgio, P. A. and Williams, P. J. B., Oxford University Press, Oxford, 248-266, 2005. 
Friedland, K. D., Stock, C., Drinkwater, K. F., Link, J. S., Leaf, R. T., Shank, B. V., Rose, J. M., Pilskaln, C. H., and Fogarty, M. J.: Pathways between primary production and fisheries yields of large marine ecosystems, Plos One, 7, e28945, doi:10.1371/journal.pone.0028945, 2012.

Fuchs, H. L. and Franks, P. J. S.: Plankton community properties determined by nutrients and size-selective feeding, Mar. Ecol.Prog. Ser., 413, 1-15, doi:10.3354/meps08716, 2010.

Fuhrman, J.: Impact of viruses on bacterial processes, in: Microbial ecology of the oceans, 1st ed., edited by: Kirchman, D. L., Wiley series in ecology and microbiology, John Wiley and Sons, New York, 327-350, 2000.

Geider, R. J.: Respiration: Taxation without representation, in: Primary productivity and biogeochemical cycles in the sea, edited by: Falkowski, P. G. and Woodhead, A. D., Plenum Press, New York, 333-360, 1992.

Geider, R., MacIntyre, H. L., and Kana, T. M.: Dynamic model of phytoplankton growth and acclimation: Responses of the balanced growth rate and chlorophyll a: carbon ratio to light, nutrient limitation and temperature, Mar. Ecol.-Prog. Ser., 148, 187200, 1997.

Griffies, S. M.: Elements of MOM4p1, NOAA/GFDL, Princeton, NJ, 377, 444 pp., 2009.

Griffies, S. M., Gnanadesikan, A., Dixon, K. W., Dunne, J. P., Gerdes, R., Harrison, M. J., Rosati, A., Russell, J. L., Samuels, B. L., Spelman, M. J., Winton, M., and Zhang, R.: Formulation of an ocean model for global climate simulations, Ocean Science, 1, 45-79, 2005.

Guilyardi, E., Wittenberg, A., Fedorov, A., Collins, M., Wang, C. Z., Capotondi, A., van Oldenborgh, G. J., and Stockdale, T.: Understanding El Nino in ocean-atmosphere general circulation models progress and challenges, B. Am. Meteorol. Soc., 90, 325-340, doi:10.1175/2008bams2387.1, 2009.

Hansen, B. W., Bjornsen, P. K., and Hansen, P. J.: The size ratio between planktonic predators and their prey, Limnol. Oceanogr., 39, 395-402, 1994.

Hansen, P. J., Bjornsen, P. K., and Hansen, B. W.: Zooplankton grazing and growth: Scaling within the 2-2000- $\mu$ m body size range, Limnol. Oceanogr., 42, 687-704, 1997.

Hegerl, G. C., Zwiers, F. W., Braconnot, P., Gillett, N. P., Luo, Y., Marengo Orsini, J. A., Nicholls, N., Penner, J. E., and Stott, P. A.: Understanding and attributing climate change, in: Climate change 2007: The physical science basis, Contribution of working group I to the fourth assessment report of the intergovernmental panel on climate edited by: Solomon, S., Qin, D., Manning, M., Chen, Z., Marquis, M., Averyt, K. B., Tignor, M., and Miller, H. L., Cambridge University Press, Cambridge UK and New York, NY, USA, 663-745, 2007.

Jackson, G. A.: A model of the formation of marine algal flocs by physical coagulation processes, Deep-Sea Res.-Pt. I, 37, 11971211, 1990.

Johnson, C. L., Leising, A. W., Runge, J. A., Head, E. J. H., Pepin, P., Plourde, S., and Durbin, E. G.: Characteristics of calanus finmarchicus dormancy patterns in the northwest atlantic, ICES J. Mar. Sci., 65, 339-350, doi:10.1093/icesjms/fsm171, 2008.

Jumars, P. A., Penry, D. L., Baross, J. A., Perry, M. J., and Frost, B. W.: Closing the microbial loop: Dissolved carbon pathway to heterotrophic bacteria from incomplete ingestion, digestion, and absorption in animals, Deep-Sea Res., 36, 483-495, 1989.
Kearney, K. A., Stock, C., and Sarmiento, J. L.: Amplification and attenuation of increased primary production in a marine food web, Mar. Ecol.-Prog. Ser., 491, 1-14, doi:10.3354/Meps10484, 2013.

Kishi, M. J., Kashiwai, M., Ware, D. M., Megrey, B. A., Eslinger, D. L., Werner, F. E., Noguchi-Aita, M., Azumaya, T., Fuji, M., Hashimoto, S., Huang, D., Iizumi, H., Ishida, Y., Kang, S., Kantakov, G. A., Kim, H.-c., Komatsu, K., Navrotsky, V. V., Smith, S. L., Tadokoro, K., Tsuda, A., Yamamura, O., Yamanaka, Y., Yakouchi, K., Yoshi, N., Zhang, J., Zuenko, Y. I., and Zvalinsky, V. I.: Nemuro-a lower trophic level model for the north pacific marine ecosystem, Ecol. Model., 202, 12-25, 2007.

Klaas, C. and Archer, D. E.: Association of sinking organic matter with various types of mineral ballast in the deep sea: Implications for the rain ratio, Global Biogeochem. Cy., 16, 1116, doi:10.1029/2001GB001765, 2002.

Landry, M. R., Al-Mutairi, H., Selph, K. E., Christensen, S., and Nunnery, S.: Seasonal patterns of mesozooplankton abundance and biomass at station aloha, Deep-Sea Res.-Pt. II, 48, $2037-$ 2061, 2001.

Lin, S. J.: A "vertically lagrangian" finite-volume dynamical core for global models, Mon. Weather Rev., 132, 2293-2307, doi:10.1175/1520-0493(2004)132<2293:Avlfdc>2.0.Co;2, 2004.

Mauchline, J.: The biology of calanoid copepods, Advances in marine biology, Academic Press, San Diego, 710 pp., 1998.

Meehl, G. A., Stocker, T. F., Collins, W. D., Friedlingstein, P., Gaye, A. T., Gregory, J. M., Kitoh, A., Knutti, R., Murphy, J. M., Noda, A., Raper, S. P. B., Watterson, I. G., Weaver, A. J., and Zhao, Z.-C.: Global climate projections, in: Climate change 2007: The physical science basis. Contribution of working group I to the fourth assessment report of the intergovernmental panel on climate change, edited by: Solomon, S., Qin, D., Manning, M., Chen, Z., Marquis, M., Averyt, K. B., Tignor, M., and Miller, H. L., Cambridge University Press, Cambridge, United Kingdom and New York, NY, USA., 589-662, 2007.

Merino, G., Barange, M., Blanchard, J. L., Harle, J., Holmes, R., Allen, I., Allison, E. H., Badjeck, M. C., Dulvy, N. K., Holt, J., Jennings, S., Mullon, C., and Rodwell, L. D.: Can marine fisheries and aquaculture meet fish demand from a growing human population in a changing climate?, Global Environ. Chang., 22, 795-806, 2012.

Munk, W. H. and Riley, G. A.: Absorption of nutrients by aquatic plants, J. Mar. Res., 11, 215-240, 1952.

Nagata, T.: Production mechanisms of dissolved organic matter, in: Microbial ecology of the oceans, edited by: Kirchman, D. L., John Wiley and Sons, Inc., New York, 121-152, 2000.

O'Brien, T. D.: Copepod: A global plankton database, Technical Memorandum, 19, 136 pp., 2005.

Pauly, D., Christensen, V., and Walters, C.: Ecopath, Ecosim, and Ecospace as tools for evaluating ecosystem impact of fisheris, ICES J. Mar. Sci., 57, 697-706, 2000.

Record, N. R., Pershing, A. J., and Maps, F.: Emergent copepod communities in an adaptive trait-structured model, Ecol. Model., 260, 11-24, doi:10.1016/j.ecolmodel.2013.03.018, 2013.

Reichler, T. and Kim, J.: How well do coupled models simulate today's climate?, B. Am. Meteorol. Soc., 89, 303-311, doi:10.1175/BAMS-89-3-303, 2008. 
Riahi, K., Rao, S., Krey, V., Cho, C. H., Chirkov, V., Fischer, G., Kindermann, G., Nakicenovic, N., and Rafaj, P.: RCP 8.5 - a scenario of comparatively high greenhouse gas emissions, Clim. Change, 109, 33-57, doi:10.1007/s10584-011-0149-y, 2011.

Roman, M. R., Adolf, H. A., Landry, M. R., Madin, L. P., Steinberg, D. K., and Zhang, X.: Estimates of oceanic mesozooplankton production: A comparison using the Bermuda and Hawaii time-series data, Deep-Sea Res.-Pt. II, 49, 175-192, 2002.

Rose, K. A., Allen, J. I., Artioli, Y., Barange, M., Blackford, J., Carlotti, F., Cropp, R., Daewel, U., Edwards, K., Flynn, K., Hill, S., Hille Ris Lambers, R., Huse, G., Mackinson, S., Megrey, B. A., Moll, A., Rivkin, R., Salihoglu, B., Schrum, C., Shannon, L., Shin, Y., Smith, S. L., Smith, C., Solidoro, C., St John, M., and Zhou, M.: End-to-end models for the analysis of marine ecosystems: Challenges, issues, and next steps, Marine and Coastal Fisheries: Dynamics, Management and Ecosystem Science, 2, 115-130, 2010.

Ruggio, R., Vichi, M., Paparella, F., and Masina, S.: Climatic trends of the equatorial undercurrent: A backup mechanism for sustaining the equatorial pacific production, J. Marine Syst., 121, 11-23, doi:10.1016/j.jmarsys.2013.04.001, 2013.

Rykaczewski, R. R. and Dunne, J. P.: Enhanced nutrient supply to the California Current ecosystem with global warming and increased stratification in an earth system model, Geophys. Res. Lett., 37, L21606, doi:10.1029/2010GL045019, 2010.

Ryther, J. H.: Photosynthesis and fish production in the sea, Science, 166, 72-76, 1969.

Sieburth, J. M., Smetacek, V., and Lenz, J.: Pelagic ecosystem structure: Heterotrophic compartments of the plankton and their relationship to plankton size fractions, Limnol. Oceanogr., 23, 12561263, 1978.

Steinacher, M., Joos, F., Frölicher, T. L., Bopp, L., Cadule, P., Cocco, V., Doney, S. C., Gehlen, M., Lindsay, K., Moore, J. K., Schneider, B., and Segschneider, J.: Projected 21st century decrease in marine productivity: a multi-model analysis, Biogeosciences, 7, 979-1005, doi:10.5194/bg-7-979-2010, 2010.
Stock, C. A. and Dunne, J. P.: Controls on the ratio of mesozooplankton production to primary production in marine ecosystems, Deep-Sea Res.-Pt. I, 57, 95-112, 2010.

Stock, C. A., Powell, T. M., and Levin, S. A.: Bottom-up and top-down forcing in a simple size-structured plankton dynamics model, J. Marine Syst., 74, 134-152, 2008.

Stock, C. A., Alexander, M. A., Bond, N. A., Brander, K. M., Cheung, W. W. L., Curchitser, E. N., Delworth, T. L., Dunne, J. P., Griffies, S. M., Haltuch, M. A., Hare, J. A., Hollowed, A. B., Lehodey, P., Levin, S. A., Link, J. S., Rose, K. A., Rykaczewski, R. R., Sarmiento, J. L., Stouffer, R. J., Schwing, F. B., Vecchi, G. A., and Werner, F. E.: On the use of IPCC-class models to assess the impact of climate on living marine resources, Prog. Oceanogr., 88, 1-27, 2011.

Stock, C. A., Dunne, J. P., and John, J. G.: Global-scale carbon and energy flows through the marine planktonic food web: An analysis with a coupled physical-biological model, Prog. Oceanogr., 120, 1-28, doi:10.1016/j.pocean.2013.07.001, 2014.

Straile, D.: Gross growth efficiencies of protozoan and metazoan zooplankton and their dependence on food concentration, predator-prey weight ratio, and taxonomic group, Limnol. Oceanogr., 42, 1375-1385, 1997.

Sumaila, U. R., Cheung, W. W. L., Lam, V. W. Y., Pauly, D., and Herrick, S.: Climate change impacts on the biophysics and economics of world fisheries, Nature Climate Change, 1, 449-456, doi:10.1038/Nclimate1301, 2011.

Suttle, C. A.: The significance of viruses to mortality in aquatic microbial communities, Microb. Ecol., 28, 237-243, 1994.

Winton, M., Adcroft, A., Griffies, S. M., Hallberg, R. W., Horowitz, L. W., and Stouffer, R. J.: Influence of ocean and atmosphere components on simulated climate sensitivities, J. Climate, 26, 231-245, doi:10.1175/Jcli-D-12-00121.1, 2013. 